\title{
Some aspects of using the nanotechnology in food industry
}

\section{Oksana Fursik, Igor Strashynskiy, Vasil Pasichniy, Andriy Marynin}

\author{
National University of Food Technologies, Kyiv, Ukraine
}

Keywords:

Nanotechnology

Food

Gums

Meat

Dioxide Silica

Synergism

Article history:

Received

20.06.2019

Received in

revised form

17.08.2019

Accepted

28.11.2019

\section{Corresponding author:}

Igor Strashynskiy

E-mail:

sim2407@ukr.net

\section{DOI:}

$10.24263 / 2310$

1008-2019-7-2-12

\section{Abstract}

Introduction. The article presents data from a literature review of the modern areas of nanotechnology application in food industry, their properties, interaction with biopolymers in food products.

Results and discussion. $\mathrm{TiO}_{2}, \mathrm{ZnO}$, and $\mathrm{SiO}_{2}$ are the most common nanoparticles used in the preparation of food products or food-related ingredients. The food additive E551 (dioxide silica $\mathrm{SiO}_{2}$ ) is mainly used as an anti-caking agent to improve the flowability of powdered or granular products and thus prevents the formation of lumps. At present, nanosized $\mathrm{SiO}_{2}$ is one of the most common nanoadditives in various branches of the food industry. Scientific studies show that silica, due to its structural features and large surface area, has high adsorption properties with respect to water, proteins, exoand endotoxins, and pathogenic microorganisms.

Numerous studies confirm the possibility of effective modification of the gum's rheological characteristics during their joint use with silica as a part of functional-technological compositions.

It was established by an experimental method that the addition of $\mathrm{SiO}_{2}$ to the hydrated soy proteins and protein preparations containing collagen led to a densification of the mixture, modifying their rheological and functional properties.

Conducted scientific studies of the use of nanocomposites in the technology of meat-containing culinary semi-finished products confirm the effectiveness of the use of finely divided silica as a texture-forming additive.

If there are nanocomposites in the food product according to the European legislation, the application of the term "nano" should be applied to the label only if about 50\% of the particles have a size in the range of 1-100 nm.

Conclusion. Nanoparticles directly affect the absorption and assimilation of nutrients due to physico-chemical modifications that occur during the interaction of food components with nanoparticles. 
Nanotechnology is the technology of directional manipulation of material objects having molecular sizes in the range of 1-100 $\mathrm{nm}$ [1]. This is one of the most promising technologies for improving the food industry. The range and direction of nanotechnology application is determined by the functionality of nanoparticles. Nanocomponents can affect the bioavailability and nutritional value of foods, as well as their functionality [2]. It was found that the biological properties (including toxicological) of nanomaterials are largely dependent on their physicochemical properties [3]. Nanomaterials exhibit fundamentally new useful properties that are absent in substances represented by continuous phases or macroscopic dispersion. One of the main reasons for the appearance of such properties is an increase in surface area, which leads to a multiple enhancement of processes due to surface (interphase) interactions. The result, characteristic of nanomaterials, is a significant increase in interactions with other materials and biological objects. [1].

The main interactions between nanoparticles and food compounds and their direction increase food safety, extend shelf life, improve taste and nutrient intake, make it possible to detect the presence of pathogenic / toxic substances, pesticides, change the functional properties of products according to the scheme shown in Figure 1 [4].

An analysis of recent scientific developments and publications indicates the promise of using finely dispersed solid nanoparticles in food products, which are characterized by limited selective wetting, and therefore are able to be at the phase boundary. Such emulsions were given the special name "Pickering emulsions", the advantages of which are higher stability, the ability to create highly concentrated systems, resistance to $\mathrm{pH}$ changes, low cost and environmental friendliness [5].

It can be argued that nanoparticles directly affect the absorption and assimilation of nutrients due to physico-chemical modifications that occur during the interaction of food components with nanoparticles [6]. The properties of nanoparticles also increase their attractiveness in terms of improving the absorption and bioavailability of additional nutrients, such as vitamins and minerals. Most studies focus on the use of nanotechnology in regulating the basic properties of packaging and food processing. [7].

According to the List of Consumer Products Based on Nanotechnology (CPI) created by the Woodrow Wilson International Centre for Scientists and the Nanotechnology Formation Project, commercial food products or food-related ingredients that include nanoparticles, $\mathrm{TiO}_{2}, \mathrm{ZnO}$ and $\mathrm{SiO}_{2}$ are the most popular [8]. These nanocomponents can be directly used in food products as additives or in the manufacture of packaging for various applications $[9,10] . \mathrm{TiO}_{2}$ nanoparticles (in the EU food industry additive with code E171) are used as white pigment [11], Ag nanoparticles (in the EU food industry additive with code E174) are used in food packaging as an antimicrobial agent, due to their antimicrobial activity against a wide range of microorganisms [12]. ZnO nanoparticles are used as a food additive or in the manufacture of packaging because of their significant antibacterial ability, especially against gram-positive bacteria [9, 13]. An important aspect for the use of $\mathrm{ZnO}$ nanoparticles in the food industry is that they enrich the product with $\mathrm{Zn}$ molecules, one of the most important microelements for humans [10]. 


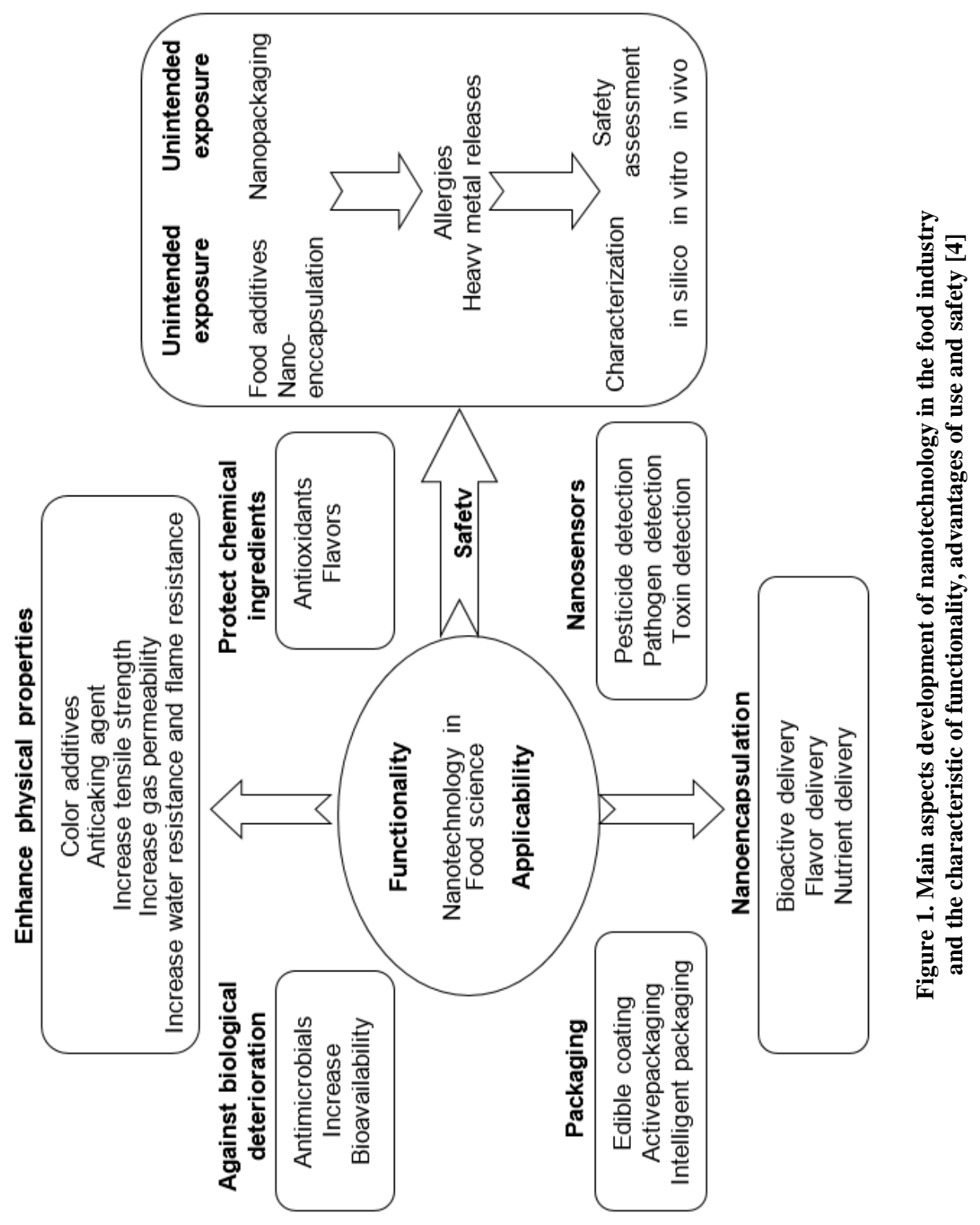


The use of organic nanoparticles in the food industry is due to their functionality, which is to improve the basic properties of products [14]. Organic nanocomposites mainly consist of a combination of organic molecules of lipids, proteins and polysaccharides. These nanoparticles can provide encapsulation, transportation and release of food additives or active ingredients in the form of micelles or liposomes, increase the solubility of certain compounds, stabilize flavorings and / or dyes, which prevents the degradation of the basic properties of the product or additive during production and storage [15].

European law No. 1169/2011 stipulated that the term "nano" should be applied to the product label if about $50 \%$ of the particles have a size in the range of $1-100 \mathrm{~nm}$. Today, for food products in the nanoforms, only calcium carbonate (E170) and vegetable carbohydrate (E153) are allowed. Other potential nano-ingredients based on titanium dioxide (E171), iron hydroxide (E172), silver (E174), gold (E175), silicon dioxide (E551), calcium silicate (E552), magnesium silicate (E553a) and talc (E553b) are under study [15].

Amorphous silicon dioxide $\left(\mathrm{SiO}_{2}\right)$ obtained by aerosol or sol-gel methods, registered and approved in the EU and the USA as a food additive E551; It is mainly used as an anticaking agent to improve the flowability of powdered or granular products and thus prevents the formation of lumps. [16, 17]. Synthetic amorphous silica is an anti-foaming agent during the production process, a means for lighting / purification of juices, oils, in brewing and as a carrier of flavouring / aromatic compounds of food products $[18,19] . \mathrm{SiO}_{2}$ is allowed to be used in an amount of up to $2 \mathrm{wt} \%$ as a direct additive in food products [20]. With the development of nanotechnology, the particle size of food additives has reached the nanoscale. Currently, nanosized $\mathrm{SiO}_{2}$ is one of the most common nanoparticles (NP) in various food industries. [21]. On its basis medical preparations are made adsorption action, carriers of biologically active substances, used as a thickener for liquid dispersion medium [22, 23]. Scientific studies show that silica, due to the structural features and large surface area (200 ... $400 \mathrm{~m}^{2} / \mathrm{g}$ ), has high adsorption properties with respect to water, proteins, exo- and endotoxins, pathogenic microorganisms. The latter should prevent or inhibit the growth of bacteria in foods $[23,24]$. Its properties lead to an increase in the use of anthropogenic silica nanoparticles in various environments of the agro-industrial and food sectors that affect humans and the environment [25].

In a number of experimental and theoretical studies, the interaction of polymer chains with colloidal particles was studied [26], however, the nature of the interactions, the molecular structures formed and their influence on the main characteristics differ significantly for nanoparticles and depending on the nature of the interaction between the polymer chain and the particle surface affects the properties of the material. The formation of deformed secondary structures in solution through the interaction between their components changes the size of the base "fraction" and at a sufficiently high concentration of particles can form a spatial network [27].

In aqueous solutions, nanoparticles and polymeric compounds interacting with each other can affect the properties of the products and materials for which they are intended. The formation of nano- and microstructures in the middle of the dispersion causes complicated rheological changes, which include an increase or decrease in viscosity, as well as gel formation. The study of the properties of biopolymers, nanocomposites and their mixtures with controlled optical, electrical, mechanical properties is of considerable interest for use in materials science, wastewater treatment and industrial separation processes, in biomedicine, biotechnology and food industry [27].

Previous studies of silica nanoparticles in polysaccharide solutions have established the formation of a gel mediated by silica nanoparticles [28]. In the work of Jordan R.M. etc. [27] the effect of silicon dioxide nanoparticles on the properties of two biopolymers with different 
conformations in solution was investigated, namely xanthan gum and locust bean gum (LBG), which are often used in food and cosmetic industries as thickeners. When mixing, both biopolymers interact with the formation of thermal gels, which are used in drug delivery systems, the formation of structures of animal products. The addition of silicon dioxide nanoparticles to the solutions of these hydrocolloids, as well as their mixtures, causes a modification of the basic structural and mechanical properties, which is manifested in a change in rheology, an increase in viscosity and elasticity.

Solutions of xanthan gum, a polyelectrolyte with a semi-rigid rodsimilar molecular structure, with using silicon dioxide in the form of a nanocomposite showed insignificant changes in viscosity over the entire range of shear rate changes and an increase in viscosity modulus with an increase the amount of silicon dioxide due to the interaction of their particles with each other and the formation of a larger number of bound sites polymer gel. This information is confirmed in our research [29].

LBG is a non-ionic compound with spiral molecules, the solutions of which are characterized by a decrease in viscosity with an increase in shear rate as it approaches Newtonian fluids. When $1 \%$ nanocomposite is added, we observed an increase viscosity and relaxation time. When $10 \%$ silicon dioxide is added, a gel-sol transition and change the viscosity characteristics has occurred. This is explained by both interaction with nanocomposites and between hydrocolloid molecules, and it is also possible for the polysaccharide surface not to be completely saturated with polymer nanocomposite molecules, which led to the formation of bridges between the molecules and particle aggregation [28].

In studies [30], there is information that the addition of silica leads to an increase viscosity characteristics aqueous solutions of guar gum by an average of $25 \%$, and after heating by $75 \%$ compared with a sample without silica. This can be explained by the formation of associations of intermolecular chains due to the introduction of silica, which leads to the formation of complex three-dimensional networks are destroyed even at low shear rates, but increase the structural viscosity of aqueous solutions.

The synergy effect from the interaction of standardized solutions modified potato starch, "Extra" starch and milk whey, when 0,3\% fumed silica is added to them, has led to an increase in the effective viscosity values, which are intensified after the heat treatment of potato starch solutions "Extra" by 2,8 times, modified starch by 4,5 times, and whey solutions by $27 \%$, which makes it possible to standardize the characteristics of meatminced emulsions with various recipes composition [31].

In mixed solutions of xanthan gum and LBG in a ratio of 1: 1, when added $1 \%$ or $10 \%$ dioxide silica, the elasticity of the gel changes. When the temperature changes in the range of $20-85^{\circ} \mathrm{C}$, solutions using a $10 \%$ nanocomposite under conditions of constant deformation were characterized by the stability of the elastic module. This indicates the ability of the hydrocolloid structure associated with the nanocomposite to counteract the influence of heat treatment, which is showed in the preservation of its basic properties [28].

This confirms the possibility of effective modification of the rheological characteristics of gums when their used together with silica as part of functional-technological compositions.

It was established by an experimental method that the addition of $\mathrm{SiO}_{2}$ to hydrated soy proteins led to compaction of the mixture, modifying their structural-mechanical and functional-technological properties. The $\mathrm{pH}$ value did not change. Based on the hypothesis about the ability of the food additives E551 to stabilize the protein-water system, the most interest is the change in the indicator of water binding capacity (WBC). The results of the studies, taking into account the rational WBC value, at the level of $85 \%$ for cooked sausage technology, indicate that the addition of silica in an amount of $0,3 \%$ increases the WBC 
value by an average of $3,6 \pm 0,1 \%$. This confirms the hypothesis that peptides and proteins can attach to silicon nanoparticles. The highest growth of WBC was recorded for the isolate and concentrate, and for the protein decrease in the maximum degree of hydration was observed using a nanocomposite. The values of the emulsion stability (ES) and emulsifying ability (EA) indicators for the isolate and concentrate indicate an increase in these indicators in samples with silica by 6-9\%, respectively. For protein, contrariwise, when silica is added, the ES and EA values decrease, and the product exfoliates. This is due to the destruction of the protein: fat: water system, which is associated, in our opinion, with the specific chemical composition of this preparation. Protein is not a pure protein preparation and includes other types of thickeners that have a syneresis with respect to $\mathrm{SiO}_{2}$ [31].

The introduction of a silica nanocomposite in an amount of $0,3 \%$ to animal origin protein preparations containing collagen of increases the WBC value of the gel of the studied samples by an average of $3,2 \pm 0,1 \%$. The results of studies WBC indicator of selected hydrated proteins after heat treatment indicate that the same amount of silica gives a more positive effect. On average, WBC indicator increases from $3 \%$ to $8 \%$, which is almost double the average for hydrated protein without heat treatment [32].

An analysis of the results given in work [22] confirms the advisability of using the food additives E551 to improve the ES and EA indicator for compositions based on a mixture of animal and plant origin protein preparations with hydrocolloids, because we observed their increase by average on 3-5\% compared with prepared samples without making it. The advantages influence of the additive E551 on these indicators is to facilitate the formation of the so-called spatial structure, which is able to hold the fat globules in its structure.

The material [33] studied the change effective viscosity of minced meat for low-calorie minced meat semi-finished products using a texturizing silica additive in the form of a nanocomposite. The obtained data indicate that, when $\mathrm{SiO}_{2}$ was added to the model minced meats, the effective viscosity increased by an average of $16,5 \%$. The combination of bamboo fiber with silica enhances the effectiveness of fiber for thickening minced meat in the range of $3-5 \%$. Through the influence that silica exerts on meat raw materials, the increase in viscosity was about $17 \%$, which indicates a significant effect of the nanocomposite on the structure formation of minced systems by interaction with meat proteins.

Conducted scientific studies [1] confirm the effectiveness of the use of highly dispersed silica as a texture-forming additive in the technology of meat-containing culinary semifinished products. Adding it in the amount of $0,3 \%$ significantly improved the effective viscosity, ductility, water-binding capacity of structured products, resulting in increased product yield and reduced cost. Silica stabilized carotene-containing protein-fat emulsions and contributed to a better combination of plant and meat components. The developed products had excellent organoleptic characteristics and high consumer value, since they were characterized by a balanced chemical composition, high content of dietary fiber and carotene.

For our research we used nanocomposites (Amorphous dioxide silica (Aerosil) E551) with a specific surface area $\mathrm{S}=232 \mathrm{~m}^{2} / \mathrm{g}$ and a corresponding average radius primary nanoparticles of $5,88 \mathrm{~nm}$ and bulk $\rho_{0} \approx 22 \Gamma / \mathrm{cm}^{3}[34,35]$. In appearance - it is a crumbly bluish-white powder or crumbly granules without taste and smell.

According to hygiene standards, amorphous dioxide silica is allowed as a food additive that prevents caking and clumping in spices and products tightly wrapped with foil, in an amount up to $30 \mathrm{~g} / \mathrm{kg}$; in dry powdered products, including sugar, in cheeses, sliced or grated, and analogues of cheeses, in salt and salt substitutes in an amount of up to $10 \mathrm{~g} / \mathrm{kg}$; in products in the form of tablets, in biologically active food additives, in sugar confectionery, except chocolate. 


\section{Food Technology}

Most often, food emulsifier E551 silicon dioxide is used as a part of the following food groups:

- Spices, seasonings, various ready-to-eat and dried spices;

- Powdered food products such as sugar, salt or flour;

- Dairy products, usually cheeses;

- Sweets and confectionery products;

- Various types of snacks, usually chips, nuts, as well as crackers and most other beer snacks;

- Alcohol products.

\section{Conclusion}

These results show that an understanding the effect of polymeric materials in the form of nanoparticles on the properties of compounds used in the food industry is a prerequisite for ensuring the forecasting and regulation of basic properties and parameters. A more complete understanding the nature of nanostructures in food products will provide greater opportunities for the rational selection, modification and recycling of raw materials. Thus, the use of nanotechnology should contribute to further improving the quality and safety of food products.

\section{References}

1. Pasichnyj V.M., Gheredchuk A.M. (2015), Vykorystannja vysokodyspersnogho kremnezemu v tekhnologhiji m'jasomistkykh produktiv ozdorovchogho sprjamuvannja, Vistnyk KhNTU. Tekhnologhija Leghkoji i Kharchovoji Promyslovosti, 4(55), pp. 124-129.

2. Srinivas P.R., Philbert M., Vu T.Q., Huang Q., Kokini J.L., Saos E., Chen H., Peterson C.M., Friedl K.E., McDade-Ngutter C., Hubbard V., Starke-Reed P., Miller N., Betz J.M., Dwyer J., Milner J., Ross S.A. (2010), Nanotechnology research: applications in nutritional sciences, J Nutr., 140, pp. 119-24.

3. He X., Aker W.G., Huang M.-J., Watts J.D., Hwang H.-M. (2015), Metal oxide nanomaterials in nanomedicine: applications in photodynamic therapy and potential toxicity, Curr Top Med Chem, 15, pp. 1887-900.

4. He X., Hwang H.-M. (2016), Nanotechnology in food science: Functionality, applicability, and safety assessment, Journal of Food and Drug Analysis, 24(4), pp. 671-681. doi:10.1016/j.jfda.2016.06.001

5. Aveyard R., Binks B.P., Clint J.H. (2003), Emulsion stabilized solely by colloidal particles, Adv. Colloid Interface Sci, 100, pp. 503-546.

6. Cao Y., Li J., Liu F., Li X., Jiang Q., Cheng S., Gu Y. (2016), Consideration of interaction between nanoparticles and food components for the safety assessment of nanoparticles following oral exposure: A review, Environmental Toxicology and Pharmacology, 46, pp. 206-210, DOI: 10.1016/j.etap.2016.07.023

7. Chau C.F., Wu S.H., Yen G.C. (2007), The development of regulations for food nanotechnology, Trends Food Sci. Technol., 18, pp. 269-80.

8. Vance M.E., Kuiken T., Vejerano E.P., McGinnis S.P., Hochella Jr. M.F., Rejeski D., Hull M.S. (2015), Nanotechnology in the real world: redeveloping the nanomaterial consumer products inventory, Beilstein. J. Nanotechnol., 6, pp. 1769-1780.

9. Bumbudsanpharoke N., Ko S. (2015), Nano-food packaging: an overview of market, migration research, and safety regulations, J. Food Sci., 80, pp. R910-R923. 
10. Wang H., Du L.J., Song Z.M., Chen X.X. (2013), Progress in the characterization and safety evaluation of engineered inorganic nanomaterials in food, Nanomedicine, 8, pp. 2007-2025.

11. Periasamy V.S., Athinarayanan J., Al-Hadi A.M., Juhaimi F.A., Mahmoud M.H., Alshatwi A.A. (2015), Identification of titanium dioxide nanoparticles in food products: induce intracellular oxidative stress mediated by TNF and CYP1A genes in human lung fibroblast cells, Environ. Toxicol. Pharmacol., 39, pp. 176-186.

12. Antony J.J., Sivalingam P., Chen B. (2015), Toxicological effects of silver nanoparticles, Environ. Toxicol. Pharmacol., 40, pp. 729-732.

13. Shi L.E., Li Z.H., Zheng W., Zhao Y.F., Jin Y.F., Tang Z.X. (2017), Synthesis, antibacterial activity, antibacterial mechanism and food applications of $\mathrm{ZnO}$ nanoparticles: a review, Food Addit. Contam Part A Chem. Anal. Control Expo. Risk Assess., 31, pp. 173-186.

14. Kang P., Qixin Z. (2016), Organic Nanoparticles in Foods: Fabrication, Characterization, and Utilization, Annual Review of Food Science and Technology, 7, pp. 245-266.

15. De La Calle I., Menta M., Klein M., Séby F. (2018), Study of the presence of micro- and nanoparticles in drinks and foods by multiple analytical techniques, Food Chemistry, 266, pp. 133-145, DOI: https://doi.org/10.1016/j.foodchem.2018.05.107.

16. Mattarozzi M., Suman M., Cascio C., Calestani D., Weigel S., Undas A., Peters R. (2017), Analytical approaches for the characterization and quantification of nanoparticles in food and beverages, Analytical and Bioanalytical Chemistry, 409(1), pp. 63-80, DOI: 10.1007/s00216-016-9946-5

17. Dekkers S., Krystek P., Peters R.J.B., Lankveld D.P.K., Bokkers B.G.H., van HoevenArentzen P.H., Bouwmeester H., Oomen A.G. (2011), Presence and risks of nanosilica in food products, Nanotoxicology, 5, pp. 393-405.

18. European Commission. (2014, November 4). JRC releases world's first certified mixture of silica nanoparticles - EU Science Hub - European Commission. URL: https://ec.europa.eu/jrc/en/news/first-certified-mixture-silica-nanoparticles

19. Barahona F., Ojea-Jimenez I., Geiss O., Gilliland D., Barrero-Moreno J. (2016), Multimethod approach for the detection and characterisation of food-grade synthetic amorphous silica nanoparticles, Journal of Chromatography A, 1432, pp. 92-100. doi:10.1016/j.chroma.2015.12.058

20. Joint FAO/WHO expert committee on food additives. Combined compendium of food additive specifications. Food and agriculture organization of the united nations: Rome, 2006.

21. Lee J.-A., Kim M.-K., Song J.H., Jo M.-R., Yu J., Kim K.-M., Kim Y.-R., Oh J.-M., Choi S.-J. (2017), Biokinetics of food additive silica nanoparticles and their interactions with food components, Colloids and Surfaces B: Biointerfaces, 150, pp. 384-392. http://dx.doi.org/10.1016/j.colsurfb.2016.11.001

22. Pasichnyj V.M., Strashynsjkyj I.M., Fursik O.P. (2015), Doslidzhennja emuljsij na osnovi bilokvmisnykh funkcionaljnykh kharchovykh kompozycij, Tekhnologhicheskii Audit $i$ Rezervy Proizvodstva, 3, pp. 51-55.

23. Chujko A.A., Poghorelыj V.K., Pentjuk A.A. (2003), Medicinskaia khimiia i klinicheskoie primenenie dioksida kremniia, Kyiv.

24. Appropriate Risk Governance Strategies for Nanotechnology Applications in Food and Cosmetics. International Risk Governance Council (IRGC). Geneva, Siwtzerland, 2009. URL: http://www.irgc.org/IMG/pdf/IRGC_PBnanofood_WEB.pdf

25. Nowack B., Brouwer C., Geertsma R.E., Heugens E.H.W., Ross B.L., Toufektsian M.C., Wijnhoven S.W.P., Aitken R.J. (2013), Analysis of the occupational, consumer and environmental exposure to engineered nanomaterials used in 10 technology sectors, Nanotoxicology 7, pp. 1152-1156.

26. Gregory J., Barany S. (2011), Adsorption and flocculation by polymers and polymer mixtures, Adv. Colloid Interface Sci., 169(1), pp. 1-12, DOI: 10.1016/j.cis.2011.06.004 
27. Kennedy J.R.M., Kent K.E., Brown J.R. (2015), Rheology of dispersions of xanthan gum, locust bean gum and mixedbiopolymer gel with silicon dioxide nanoparticles, Materials Science and Engineering, 48, pp. 347-353.

28. Oliveira F., Monteiro S.R., Barros-Timmons A., Lopes-da-Silva J.A. (2010), Weak-gel formation in dispersions of silica particles in a matrix of a non-ionic polysaccharide: Structure and rheological characterization, Carbohydrate Polymers., 82(4), pp. 1219-1227, DOI:10.1016/j.carbpol.2010.06.046

29. Strashynskyi I.M., Fursik O.P., Pasichnyi V.M., Marynin A.I. (2016), Doslidzhennia reolohichnykh vlastyvostei kharchovykh hidrokoloidiv, Prohresyvni Tekhnika ta Tekhnolohii Kharchovykh Vyrobnytstv Restorannoho Hospodarstva i Torhivli. Zbirnyk naukovykh prats, 2(24), pp. 288-298.

30. Pasichnyi V.M., Marynin A.I., Moroz O.O., Heredchuk A.M. (2015), Rozrobka kombinovanykh bilkovo-zhyrovykh emulsii dlia kovbas i napivfabrykativ z miasom ptytsi, Skhidno-Yevropeiskyi Zhurnal Peredovykh Tekhnolohii, 1(6), pp. 32-38

31. Ivanov S.V., Pasichnyi V.M., Strashynskyi I.M., Fursik O.P. (2014), Vplyv nanokompozytu na funktsionalni pokaznyky bilkovykh preparativ roslynnoho pokhodzhennia, Tekhnolohiia Vyrobnytstva i Pererobky Produktsii Tvarynnytstva, 2, pp. 74-78

32. Ivanov S.V., Pasichnyi V.M., Strashynskyi I.M., Fursik O.P. (2014), Vplyv nanokompozytiv na pokaznyky bilkovykh preparativ tvarynnoho pokhodzhennia. Naukovyi Visnyk LNUVMBT imeni S.Z. Gzhytskoho, 3(60), pp. 57-61.

33. Ivanov S., Pasichnyj V., Strashinskij I., Marinin A., Fursik O., Krepak V. (2014), Polufabrikaty iz mjasa indejki s ispol'zovaniem teksturoformirujushhih napolnitelej, Maisto chemija ir technologija, 48(2), pp. 25-33

34. (2009), International Risk Governance Council, Policy Brief: Appropriate Risk Governance Strategies for Nanotechnology Applications in Food and Cosmetics, Geneva.

35. Department of Industry, Innovation, Science and Research '(2009) Market Attitude Research Services, Australian Community Attitudes about Nanotechnology - 2005-2009. Department of Industry, Innovation, Science and Research, Australia, 2009. 